\title{
Trace elements in Athyrium distentifolium from alpine vegetation in the Karkonosze, SW Poland
}

\author{
Aleksandra Kazienko • Karol Torzewski • Bronisław Wojtuń • \\ Aleksandra Samecka-Cymerman (D) - Lucyna Mróz • \\ Alexander J. Kempers
}

Received: 25 January 2020 / Accepted: 21 June 2020 /Published online: 3 July 2020

(C) The Author(s) 2020

\begin{abstract}
The Karkonosze National Park is affected by long-distance metal air transport of anthropogenic contamination as well as by tourist activity. Therefore, concentrations of $\mathrm{Cd}, \mathrm{Co}, \mathrm{Cr}, \mathrm{Cu}, \mathrm{Fe}, \mathrm{Mn}, \mathrm{Ni}, \mathrm{Pb}$ and $\mathrm{Zn}$ were evaluated in soil as well as in vital and non-vital fronds of Athyrium distentifolium Opiz collected in the middle of the growing season from glacial cirques in the Karkonosze. Additionally, fronds of the same species
\end{abstract}

Electronic supplementary material The online version of this article (https://doi.org/10.1007/s10661-020-08438-4) contains supplementary material, which is available to authorized users.

A. Kazienko · K. Torzewski · B. Wojtuń ·

A. Samecka-Cymerman $(\bowtie) \cdot$ L. Mróz

Department of Ecology, Biogeochemistry and Environmental

Protection, ul. Kanonia 6/8, 50-328 Wrocław, Poland

e-mail: aleksandra.samecka-cymerman@uwr.edu.pl

\author{
A. Kazienko \\ e-mail: aleksandra.kazienko@uwr.edu.pl \\ K. Torzewski \\ e-mail: karol.torzewski@uwr.edu.pl \\ B. Wojtuń \\ e-mail: bronislaw.wojtun@uwr.edu.pl \\ L. Mróz \\ e-mail: lucyna.mroz@uwr.edu.pl
}

\section{A. J. Kempers}

Department of Environmental Science, Faculty of Sciences, Institute for Water and Wetland, Research Radboud University, Heijendaalseweg 135, 6525 AJ Nijmegen, Netherlands e-mail: L.Kempers@science.ru.nl turning brown in autumn were collected from the same sampling sites. The health of ferns was impacted by the contents of $\mathrm{Co}, \mathrm{Cu}, \mathrm{Fe}, \mathrm{Mn}, \mathrm{Ni}, \mathrm{Pb}$ and $\mathrm{Zn}$ in fronds, which may indicate that $A$. distentifolium uses elements accumulated in its tissues as defence against pathogens. Individuals from higher altitudes contained higher concentrations of $\mathrm{Cd}, \mathrm{Cu}, \mathrm{Ni}, \mathrm{Fe}$ and $\mathrm{Pb}$ than those from lower altitudes. Autumn fronds of A. distentifolium contained a significantly higher concentration of $\mathrm{Cr}$, $\mathrm{Cu}, \mathrm{Fe}, \mathrm{Mn}$ and $\mathrm{Pb}$ than vital summer fronds, which may indicate sequestration of these elements in senescing fronds probably to remove potentially harmful metals. Non-vital ferns were a better accumulator of $\mathrm{Pb}$ than vital ones, while both types of ferns accumulated $\mathrm{Mn}$ in a similar way.

Keywords Fern $\cdot$ Metal $\cdot$ Altitude $\cdot$ High mountain

\section{Introduction}

The Karkonosze is the largest mountain chain in the Sudety, SW Poland, formed by a crystalline massif reaching up to $1603 \mathrm{~m}$ a.s.l. (Urban et al. 2017). Granites, with an admixture of crystalline schists and gneisses, form the main acidic bedrock (Mochnacka and Banaś 2000). Vegetation of the high parts of the Karkonosze is described by Štursa (1998) as arcticalpine tundra. The longitudinal location of these mountains favours influence of W-E flow (from the former 'black triangle') of long-range pollution transport from mining and chemical industries as well as power plants 
(Pusz 2016; Wojtuń et al. 2013a, b 2017). One of the constituents of contaminants is nondegradable metals easy accumulated in biota and incorporated in soils with a negative impact on ecosystems (Kabata-Pendias 2001a; Szopka et al. 2011). Accordingly, pollution influence on particular high mountain ecosystems of the Karkonosze must be precisely controlled (Štursa 1998). The best tool which reflects chemistry of the environment is elemental composition in the biomass of plant bioindicators (Holoubek et al. 2000; Schmidt et al. 2010). Ferns are able to survive in polluted soils, especially in active mining areas. They are good indicators, e.g. of arsenic and copper deposits (Kachenko et al. 2007; Chang et al. 2009), or valuable indicators of metalliferous soils (Cornara et al. 2007; Kachenko et al. 2007). According to Kachenko et al. (2007), these plants are able to accumulate also $\mathrm{Cd}, \mathrm{Cr}, \mathrm{Ni}, \mathrm{Pb}$ and $\mathrm{Zn}$ and may be utilised in the phytoremediation of contaminated soils. Such abilities and additionally tolerance to many environmental extreme factors suggest that ferns may be useful indicators of environmental pollution (Chang et al. 2009). Rybczyński and Mikuła (2011) are also of the opinion that fern gametophytes may be used as models for plant response to various contamination aspects. Studies of the tolerance of terrestrial ferns to metals in the Karkonosze are rather scarce, and therefore, the concentration of trace elements for this research was evaluated in Athyrium distentifolium Opiz fronds and soil from its sampling sites. The genus Athyrium may be an example of ferns with the abovementioned abilities (Zhang et al. 2014; Kamachi et al. 2015). A. distentifolium, the alpine lady-fern, is a circumpolar arctic-montane species growing at high altitude sites. This is a chionophilous fern and thus prefers long-standing snow cover (McHaffie 2005). This author believes that deep snow cover protects $A$. distentifolium from low temperatures in winter and protects early rise in spring. These abilities are an advantage in competition with other species (McHaffie 2005). In the Karkonosze, A. distentifolium forms Athyrietum distentifolii Hadač 1955 em. W. Mat 1960 association which especially inhabits glacial cirques (Fudali 2010; Żołnierz et al. 2012). A. distentifolium is also a dominating species of the understory in the forests of the Karkonosze whose coverage has increased during the industrial era of air pollution (Vacek et al. 1999). However, in the last years, some dieback of the Athyrietum distentifolii subalpine tall fern community is observed in the Karkonosze. The cause of the dieback is not known
(Dunajski et al. 2016; T. Szymura personal communication). Accordingly, it was examined whether a difference could be observed in the concentration of trace elements in vital and non-vital fronds. The aim of this study was to determine $\mathrm{Cd}, \mathrm{Co}, \mathrm{Cr}, \mathrm{Cu}, \mathrm{Fe}, \mathrm{Mn}, \mathrm{Ni}$, $\mathrm{Pb}$ and $\mathrm{Zn}$ in soil as well as in both vital and non-vital fronds of A. distentifolium collected in the middle of the growing season from glacial cirques and in their vicinity in the Karkonosze. Additionally, fronds of the same plant turning brown in autumn were collected from the same sampling sites. The selected metals were indicated in former investigation as increased contamination in this area due to former 'black triangle' long-range emissions (Wojtuń et al. 2013a). Measuring their accumulation in plants contributes to the knowledge of their dispersion and possible protection measures to be taken. The tested hypotheses in this study are the following: (1) Non-vital summer fronds contain significantly higher concentrations of certain trace elements, which may suggest that these metals are accumulated in A. distentifolium tissues as defence against pathogens; (2) metal contents in summer green fronds of A. distentifolium are significantly lower than those, while they are turning brown in autumn because the excess of metals is withdrawn; and (3) A. distentifolium accumulates certain metals proportionally to their concentration in soil and thus might provide information on the concentration of these elements present in the environment.

\section{Material and methods}

Sampling design

The investigation was carried out in the Karkonosze National Park (Fig. 1). Vital fronds of A. distentifolium as well as non-vital fronds from 28 sites were collected in early July (referred to as summer). Fronds turning brown were collected in early October (referred to as autumn). Collecting rhizomes in the Karkonosze National Park was not allowed, and the comparison of metal concentrations in summer and autumn fronds was expected to demonstrate which metals were withdrawn to the decaying fronds to protect the fern from their toxic influence. Samples were collected from open space not influenced by throughfall from canopies (Markert et al. 1996; Harmens et al. 2004) in mountain pasture/meadow below Łabski Peak (sites 1-3), Mały 
Śnieżny Cirque (sites 4-6), Duży Śnieżny Cirque (sites 7-9), Odrodzenie mountain hotel (sites 10-12), Wielki Staw Cirque (sites 13-15), Mały Staw Cirque (sites 1620), Łomniczka Cirque (sites 21-23), and Domek Myśliwski Karkonosze National Park Ecological Education Centre and in the vicinity of walking trails (sites 24-28). The geographical coordinates of the sample locations are given in ESM 1. The samples were divided into two groups: (1) collected on the border of the upper forest belt and subalpine belt (sites 10-12, 24-28) and (2) collected in the subalpine belt $(7-9,13-15,16-20$, 21-23). At each site, three replicates of fronds, both vital and non-vital (where present), were collected at random within a $25 \mathrm{~m} \times 25 \mathrm{~m}$ square. Additionally, samples of topsoil ( $0-10-\mathrm{cm}$ depth) were collected (3 replicates) from each square in summer. The metal level in unpolluted soils depends on factors, such as parent rock geochemistry (Kabata-Pendias 2001a). However, the Karkonosze soils were influenced by long-range fallout contamination (Kabała and Szerszeń 2002). Thus, the evaluation of metal reference levels was difficult. In all the examined sites, parent rock consisted of granite, and it may be supposed that the geochemistry of soil developed on this granite was comparable in the investigated area (Waroszewski et al. 2013). Soil pH was acidic (Table 1). Fronds were not washed but cleaned of litter and mineral particles (Aboal et al. 2004; Oliva and Rautio 2004).

\section{Soil and plant analysis}

Soil particulates $>2 \mathrm{~mm}$ were removed with a Morek Multiserw LPzE-2e sieve shaker, and for homogenisation, a Fritsch Pulverisette mortar grinder was used. Dried frond samples were homogenised in a laboratory mill (IKA M20 Labortechnik). Both soil and frond samples were dried $\left(50^{\circ} \mathrm{C}\right)$ until constant weight. Plant available metals $(\mathrm{Cd}, \mathrm{Co}, \mathrm{Cr}, \mathrm{Cu}, \mathrm{Fe}, \mathrm{Mn}, \mathrm{Ni}, \mathrm{Pb}$ and $\mathrm{Zn}$ ) in soil were evaluated by extraction with $1 \mathrm{M}$ ammonium acetate-EDTA ( $\mathrm{pH} 4.65$ ) for $30 \mathrm{~min}$ (10 g dry soil in $100 \mathrm{~mL}$ ) (Cottenie et al. 1982). Total concentrations of metals in soil and concentration of metals in fronds were evaluated as follows: $300 \mathrm{mg}$ of soil or plant samples (dry weight in triplicate) was digested with $65 \%$ ultrapure nitric acid $(3 \mathrm{~mL})$ and $70 \%$ ultrapure perchloric acid $(2 \mathrm{~mL})$ in a microwave oven (CEM Mars 5). Subsequently, deionised water was used for diluting the samples. The content of Fe, $\mathrm{Mn}$ and $\mathrm{Zn}$ was analysed by FAAS (Avanta PM from $\mathrm{GBC}$ ) and $\mathrm{Cd}, \mathrm{Co}, \mathrm{Cr}, \mathrm{Cu}$,
$\mathrm{Ni}$ and $\mathrm{Pb}$ by GFAAS (PinAAcle 900Z from PerkinElmer). All trace elements were controlled with Atomic Absorption Standard Solutions (Sigma Chemical Co.) and blanks containing the same matrix as the samples and were treated in the same way as the samples. Resulting metal contents were expressed on a dry weight basis. The accuracy of the methods was controlled with Chestnut Soil, Bainaimao and Bayan Obo, Neil Mongol in China GBW07402 (GSS-2) and Poaceae (mixture) IPE 952WEPAL Certified Reference Materials.

Statistical analysis

One-way ANOVA $(p<0.05)$ followed by a post hoc Tukey test was applied to control the statistical significance of differences between sites with respect to the concentration of metals in soils and both types of fronds. Normal distribution was obtained by BoxCox transformation of data (Zar 1999). Shapiro-Wilk's $W$ test was applied for normality and the Brown-Forsythe test for the homogeneity of variances (Brown and Forsythe 1974; Argaç 2004). The difference in the content of metals between vital summer and autumn fronds was compared with the $t$ test (Zar 1999). ANCOVA analysis was applied on BoxCox transformed data for comparison of the metal content in fronds of A. distentifolium in relation to the available metal content in soil, altitude of the sampling sites (group 1 and 2) and health status (vital vs non-vital).

To compare the accumulation of the same elements from soil by vital and non-vital $A$. distentifolium, an equal slopes model on BoxCox transformed data was applied. In this model, the independent variable (covariate) was the concentration of an element in soil, the dependent variable was the concentration of the same element in fronds of A. distentifolium, and the categorical predictor variable was the health status. The interaction between the health status and concentration of an element in soil tests the hypothesis that the slopes of regression lines were equal between vital and non-vital fronds. If the slopes were not significantly different, we further tested whether the intercepts were equal. When the slopes were significantly different, a model of heterogeneity of slopes was fitted. Interaction between the health status and concentration of an element in soil tests the unequal slopes hypothesis. In this model, the independent variable (covariate) was the concentration of an element in soil, the dependent 


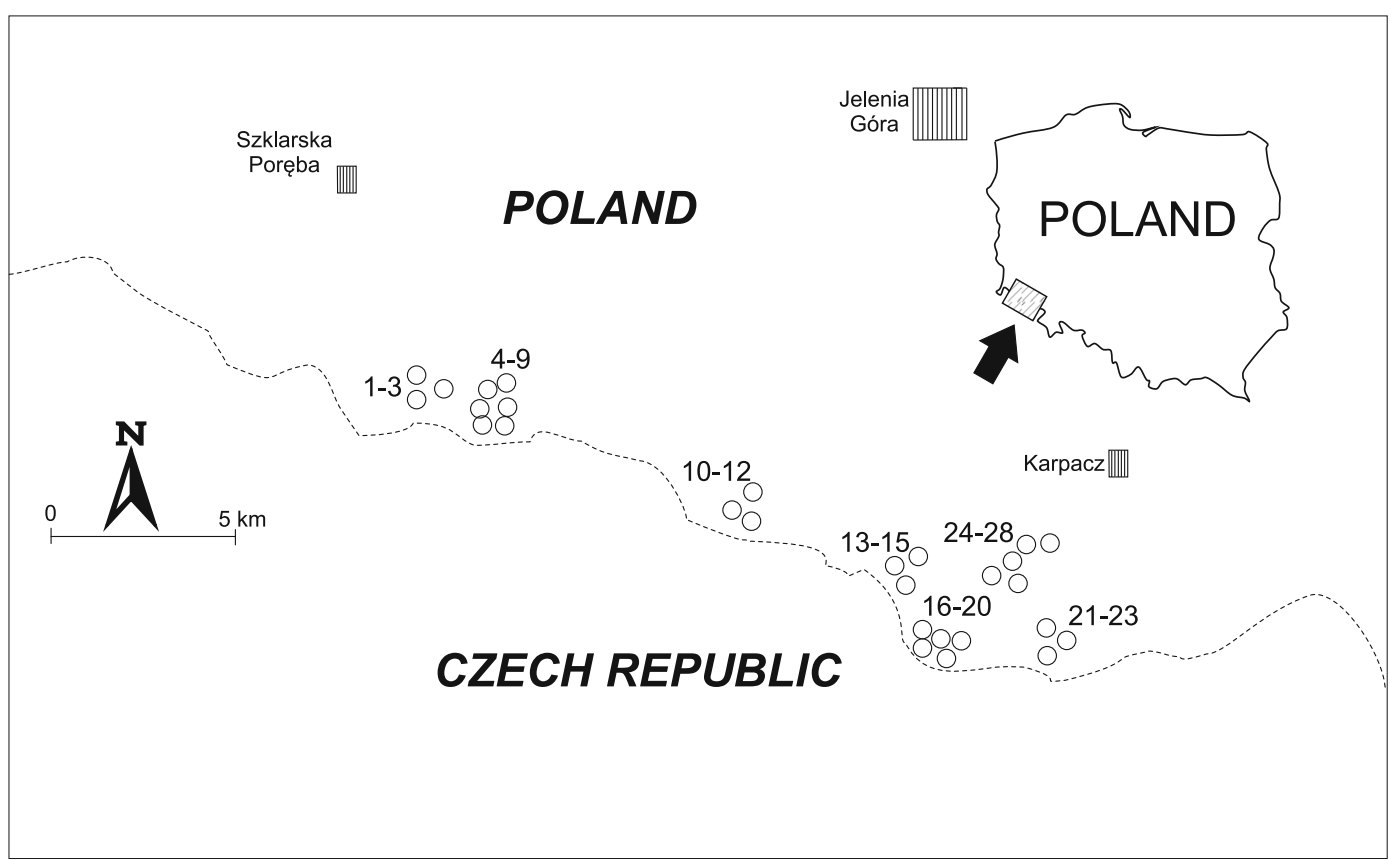

Fig. 1 Location of the sampling sites

variable was the concentration of the same element in A. distentifolium, and the categorical predictor variable was the health status (Snedecor and Cochran 1989; Quinn and Keough 2002).

Principal component and classification analysis (PCCA) was used for the evaluation of the similarity of $\mathrm{Cd}, \mathrm{Co}, \mathrm{Cr}, \mathrm{Cu}, \mathrm{Fe}, \mathrm{Mn}, \mathrm{Ni}, \mathrm{Pb}$ and $\mathrm{Zn}$ contents in frond samples (Legendre and Legendre 1998). Co and
Ni were applied as supplementary variables because of the lowest correlation coefficients with the 1st and 2nd factors for these elements (Zuur et al. 2007).

The bioaccumulation factor, BF, was calculated as the ratio between metal content in vital and non-vital summer fronds to plant available content in soil (Kłos 2009). The Mann-Whitney $U$ test was applied for comparison of BF between vital and non-vital fronds.

Table 1 Minimum and maximum values, median and average deviation (AD) of summer concentrations ( $\mathrm{mg} \mathrm{kg}^{-1}$ ) of total and available elements for plants in soil from the Karkonosze

\begin{tabular}{|c|c|c|c|c|c|c|c|c|c|}
\hline Element & $\begin{array}{l}\text { Minimum } \\
\text { Total }\end{array}$ & Maximum & Median & $\mathrm{AD}$ & Threshold & $\begin{array}{l}\text { Minimum } \\
\text { Available }\end{array}$ & Maximum & Median & $\mathrm{AD}$ \\
\hline $\mathrm{pH}$ & 3.8 & 4.9 & 4.3 & 0.2 & & & & & \\
\hline $\mathrm{Cd}$ & 0.1 & 1.0 & 0.3 & 0.2 & & 0.01 & 0.5 & 0.1 & 0.07 \\
\hline $\mathrm{Co}$ & 0.04 & 3.6 & 0.8 & 0.7 & $\leq 5$ & 0.01 & 0.5 & 0.1 & 0.09 \\
\hline $\mathrm{Cr}$ & 0.2 & 14 & 5.6 & 2.4 & $\leq 100$ & 0.04 & 0.7 & 0.2 & 0.13 \\
\hline $\mathrm{Cu}$ & 6.8 & 68 & 33 & 13 & $\leq 100$ & 0.81 & 27 & 7.2 & 3.69 \\
\hline $\mathrm{Fe}$ & 833 & 14,440 & 5530 & 2530 & & 168 & 2689 & 701 & 305 \\
\hline $\mathrm{Mn}$ & 9.5 & 280 & 92 & 52 & $\leq 1500$ & 1.1 & 86 & 15 & 14 \\
\hline $\mathrm{Ni}$ & 0.9 & 9.9 & 3.7 & 13 & $\leq 100$ & 0.02 & 3.2 & 0.5 & 0.58 \\
\hline $\mathrm{Pb}$ & 13 & 252 & 99 & 47 & $\leq 100$ & 18 & 177 & 51 & 30 \\
\hline $\mathrm{Zn}$ & 8.4 & 105 & 44 & 17 & $\leq 300$ & 0.9 & 58 & 4.3 & 8.7 \\
\hline
\end{tabular}

The data in the column threshold are environmental limits admissible for clean soil (Kabata-Pendias 2001) 
The Dell Inc. version 13 (2015) program was applied for statistical evaluation.

\section{Results and discussion}

One-way ANOVA showed that there were statistically significant differences in the concentration of the investigated metals in soils as well as fronds (both in summer and autumn samples) among the sites. The total maximum content of trace elements in soil (Table 1) exceeded the average values for unpolluted soils $\left(\mathrm{mg} \mathrm{kg}^{-1}\right): \mathrm{Cd}<0.5, \mathrm{Cu}<15, \mathrm{~Pb}<25$ and $\mathrm{Zn}<70$ (Kabata-Pendias 2001b). Soil from A. distentifolium sites contained higher upper concentrations of metals than the soil of the same species from Sudety valleys (Łomniczka and Sowia), Cd 0.1-0.5, Co 0.4-3.2, Cu 2.6-21, Mn 8-234 and Zn 13-62, and lower upper concentrations of $\mathrm{Cr} 1.3-20$ and Fe 1416-20,100 (Krawczyk et al. 2006). Especially distinctive were total $\mathrm{Pb}$ contents which in some sites were higher than the admissible $100 \mathrm{mg} \mathrm{kg}^{-1}$ for cultivated soils (Table 1). High concentration of this element in Karkonosze soil was also reported by Kabała and Szerszeń (2002) and Wojtuń et al. (2017). Upper plant available soil concentrations of trace elements from A. distentifolium sites (Table 1) were higher for $\mathrm{Cu}, \mathrm{Mn}, \mathrm{Ni}$ and $\mathrm{Pb}$ and lower for $\mathrm{Cd}, \mathrm{Cr}, \mathrm{Fe}$ and $\mathrm{Zn}$ than those established by Wojtun et al. (2017) for soils in the Karkonosze $\left(\mathrm{mg} \mathrm{kg}^{-1}\right)$ : Cd 0.001-0.7, Cr 0.002-4.4, Cu 0.7-4.3, Fe 97-6220, Mn $0.2-46$, Ni $0.002-2.1, \mathrm{~Pb} 12-77$ and $\mathrm{Zn} 0.6-88$. The plant available form of $\mathrm{Pb}$ in soil in some sites was also higher than the admissible level of this element for cultivated soils (Table 1).

The summer fronds of $A$. distentifolium from the Karkonosze subalpine belt (Table 2) contained higher upper concentrations of $\mathrm{Cd}, \mathrm{Cu}, \mathrm{Fe}, \mathrm{Ni}$ and $\mathrm{Zn}$ and fronds collected from lower altitudes contained higher upper concentrations of $\mathrm{Cd}$ and Fe than ferns Dryopteris filix-mas and Pteridium aquilinum collected by Kozanecka et al. (2002) from an unpolluted nature reserve in Poland $(\mathrm{Cd} 0.3-0.8, \mathrm{Cr} 0.4-1.7, \mathrm{Cu} 6.4-13$, Fe 58-115, Mn 60-1062, Ni 2.2-11 and Zn 11-58 in $\mathrm{mg} \mathrm{kg}^{-1}$ ).

ANCOVA analysis (Table 3) revealed that the concentration of $\mathrm{Pb}$ in fronds was influenced by the content of these elements available for plants in soil, by altitude and by the health status. $\mathrm{Cu}, \mathrm{Fe}$ and $\mathrm{Ni}$ concentrations in fronds were affected by altitude and the health status; the concentration of $\mathrm{Mn}$ in fronds was influenced by the content of Mn available for plants in soil and the health status, and the concentration of $\mathrm{Co}$ and $\mathrm{Zn}$ in fronds was influenced by the health status. Thus, the health status of ferns was influenced by the contents of $\mathrm{Co}, \mathrm{Cu}, \mathrm{Fe}, \mathrm{Mn}$, $\mathrm{Ni}, \mathrm{Pb}$ and $\mathrm{Zn}$ in fronds (Table 3). Because no investigations into the problem of the dieback of A. distentifolium in the Karkonosze were performed, the explanation must be speculative. Plants may use elements accumulated in their tissues as defence against pathogens (Fones et al. 2010; Cheruiyot et al. 2013). For instance, Mn application may provide such protection to some plant species (Eskandari et al. 2018). Iron is reported as necessary for microbial pathogens thus organisms evolved mechanisms of suppressing this metal as protection against invasion by pathogens (Becker and Skaar 2014). Zinc is used in defence either by lowering the amount to deprive the pathogen of the metal or by increasing the amount to cause lethal effects in pathogens (Weiss and Carver 2018; Fones et al. 2019). Morkunas et al. (2018) report that both the hormetic effect (effect of metals at low doses) and toxic doses of trace metals may enhance plant resistance against pathogens. However, why non-vital fronds contained higher levels of certain metals needs further investigation. Results of simple linear regression showing a positive relation between plant available $\mathrm{Mn}$ and $\mathrm{Pb}$ in soil and in A. distentifolium for both vital and non-vital plants may give some insight. An equal slopes model showed that there was no significant interaction between the health status (vital and non-vital ferns) and concentration of Mn available in soil $\left(F_{1.80}=0.47, p=0.49\right)$, indicated by homogeneous slopes of regression lines (ESM 2). This means that the relationship between the concentration of $\mathrm{Mn}$ available in soil and concentration of $\mathrm{Mn}$ in ferns was similar in vital and non-vital ferns. Significant differences in intercept were found among vital and non-vital ferns $\left(F_{1.81}=9.29, p<0.0001\right)$ : the regression line for non-vital ferns was higher than the line for vital ferns. This indicates that non-vital ferns would have higher Mn concentration at any concentration of Mn available in soil. An equal slopes model showed that there was a significant interaction between the health status (vital and non-vital ferns) and concentration of $\mathrm{Pb}$ available in soil $\left(F_{1.80}=4.89, p<0.05\right)$, indicating heterogeneous slopes (ESM 3 ), that is, slopes of the regression lines were not parallel. This indicates that the relationship between $\mathrm{Pb}$ concentration in ferns and that available in soil differs between vital and non- 
Table 2 Minimum and maximum values, median and average deviation (AD) of the summer concentration $\left(\mathrm{mg} \mathrm{kg}^{-1}\right)$ of trace elements in Athyrium distentifolium from group 1 (sites situated on the border of the upper forest belt and subalpine belt, no 10-12, 24-28) and group 2 (sites situated in the subalpine belt, no 7-9, 13-15, 16-20, 21-23)
A. distentifolium 1

\begin{tabular}{|c|c|c|c|c|c|c|c|c|}
\hline & Minimum & Maximum & Median & $\mathrm{AD}$ & Minimum & Maximum & Median & $\mathrm{AD}$ \\
\hline $\mathrm{Cd}$ & 0.2 & 1.2 & 0.7 & 0.2 & 0.2 & 3.0 & 0.8 & 0.4 \\
\hline Co & $<0.04$ & 0.2 & 0.04 & 0.03 & $<0.04$ & 0.4 & 0.1 & 0.1 \\
\hline $\mathrm{Cr}$ & 0.03 & 0.6 & 0.3 & 0.2 & 0.1 & 0.6 & 0.2 & 0.1 \\
\hline $\mathrm{Cu}$ & 5.5 & 10 & 7.1 & 0.9 & 5.7 & 24 & 8.9 & 2.3 \\
\hline $\mathrm{Fe}$ & 18 & 154 & 63 & 35 & 51 & 185 & 71 & 20 \\
\hline $\mathrm{Mn}$ & 123 & 814 & 253 & 160 & 117 & 1025 & 343 & 108 \\
\hline $\mathrm{Ni}$ & 0.7 & 6.7 & 1.8 & 0.8 & 0.9 & 21 & 5.9 & 3.7 \\
\hline $\mathrm{Pb}$ & 0.2 & 1.5 & 0.6 & 0.3 & 0.4 & 4.8 & 1.5 & 0.9 \\
\hline $\mathrm{Zn}$ & 23 & 46 & 32 & 4.2 & 20 & 90 & 31 & 11 \\
\hline
\end{tabular}

vital ferns. The fitted regression line of $\mathrm{Pb}$ concentration in ferns to the concentration of $\mathrm{Pb}$ available in soil had a slope higher in non-vital than vital ferns (2.04 and 0.61, respectively). This indicates that $\mathrm{Pb}$ concentration in non-vital ferns increased more steeply with the concentration of $\mathrm{Pb}$ available in soil than in vital ferns (regression slope higher for the former). Therefore, non-vital ferns accumulated more $\mathrm{Pb}$ with the increasing concentration of $\mathrm{Pb}$ available in soil than vital ferns. Thus, the effect of the health status on $\mathrm{Pb}$ concentration in fronds was different for different concentrations of $\mathrm{Pb}$ available in soil. Above-mentioned results may point that higher accumulation of $\mathrm{Pb}$ in non-vital $A$. distentifolium may be caused by an increasing demand for protection against potential pathogens. Especially that ferns growing at higher altitudes, containing more $\mathrm{Pb}$ (Table 3), were much more healthy with less than $5 \%$ of the population with symptoms of dieback (K. Torzewski personal communication). However, for a better understanding of these processes, more investigation is required. The evaluated model may be applied for describing the mechanism of dependence between $\mathrm{Pb}$ concentration in soil and $\mathrm{Pb}$ in ferns depending on their health status.

ANCOVA analysis also revealed that the concentration of $\mathrm{Cd}, \mathrm{Cu}, \mathrm{Fe}, \mathrm{Ni}$ and $\mathrm{Pb}$ in fronds of A. distentifolium was influenced by the altitude of the sampling sites. The content of $\mathrm{Cd}, \mathrm{Ni}$ and $\mathrm{Zn}$ in this species collected in the Tatra National Park was the highest in ferns of the same species growing at the highest altitudes (Samecka-Cymerman et al. 2012). An increased content of trace elements with altitude was also observed for 16 moss species investigated in the western Caucasus Mountains as well as in the Alps for Pleurozium schreberi and Hylocomium splendens (Zechmeister 1995; Shetekauri et al. 2015). In the mountains, the amounts of atmospheric metal deposition may vary locally. The bulk of dry and wet deposition in the sampling locations depends on their height above sea level (Gerdol and Bragazza 2006). This phenomenon in the high parts of the Karkonosze may be explained by anemo-orographic systems (Jeník 1961) favouring deposition of trace elements transported over long distances with high speed winds, among others (Kováŕ 2015).

Because it was difficult to distinguish vital and nonvital fronds in the autumn fronds, comparison with the $t$ test was performed on trace element concentrations in summer (Table 4) and autumn plants (ESM 4) pooled together with no regard of the health status. The results show that the latter contained a significantly lower content of $\mathrm{Zn}(p<0.001)$ and a significantly higher concentration of $\mathrm{Cr}, \mathrm{Fe}, \mathrm{Mn}, \mathrm{Pb}$ (all at $p<0.001$ ) and $\mathrm{Cu}$ $(p<0.05)$. The autumn fronds contained up to 3.2 times less $\mathrm{Zn}$ and up to 24, up to 3, up to 8, up to 7 and up to 65 times more $\mathrm{Cr}, \mathrm{Cu}, \mathrm{Fe}, \mathrm{Mn}$ and $\mathrm{Pb}$, respectively, than the fronds collected in summer. Thus, these metals seem to be sequestrated in senescing fronds probably to reduce the concentration of potentially harmful metals (Kachenko et al. 2007). Copper and Mn were not resorbed from senescing tissues to rhizomes by the fern Dennstaedtia punctilobula (Killingbeck et al. 2002). Iron and $\mathrm{Mn}$ are usually retained in older leaves of crop 
Table 3 Analysis of covariance (ANCOVA, BoxCox transformed) for the effects of the health status (vital vs non-vital) and altitude of the sampling sites and variation among the sites in the concentration of plant available metals $\left(\mathrm{mg} \mathrm{kg}^{-1}\right)$ in soil and in the concentration of metals $\left(\mathrm{mg} \mathrm{kg}^{-1}\right)$ in fronds of Athyrium distentifolium in summer

\begin{tabular}{|c|c|c|c|c|c|c|c|c|c|c|c|}
\hline & & Df & MS & $\mathrm{F}$ & $\mathrm{p}$ & & & Df & MS & $\mathrm{F}$ & $p$ \\
\hline \multirow[t]{3}{*}{$\mathrm{Cd}$} & Soil & 1 & 0.017 & 0.06 & NS & Mn & Soil & 1 & 1.98 & 9.01 & $<0.01$ \\
\hline & Health & 1 & 0.11 & 0.38 & NS & & Health & 1 & 2.68 & 12.21 & $<0.001$ \\
\hline & Altitude & 1 & 1.57 & 5.42 & $<0.05$ & & Altitude & 1 & 0.71 & 3.22 & NS \\
\hline \multirow[t]{3}{*}{ Co } & Soil & 1 & 0.08 & 0.63 & NS & $\mathrm{Ni}$ & Soil & 1 & 0.09 & 0.20 & NS \\
\hline & Health & 1 & 0.61 & 4.89 & $<0.05$ & & Health & 1 & 6.91 & 16.06 & $<0.001$ \\
\hline & Altitude & 1 & 0.27 & 2.12 & NS & & Altitude & 1 & 14.04 & 32.64 & $<0.001$ \\
\hline \multirow[t]{3}{*}{$\mathrm{Cr}$} & Soil & 1 & 3.89 & 19.02 & $<0.001$ & $\mathrm{~Pb}$ & Soil & 1 & 8.37 & 24.10 & $<0.001$ \\
\hline & Health & 1 & 0.66 & 3.23 & NS & & Health & 1 & 2.07 & 5.96 & $<0.05$ \\
\hline & Altitude & 1 & 0.22 & 1.06 & NS & & Altitude & 1 & 13.64 & 39.28 & $<0.001$ \\
\hline \multirow[t]{3}{*}{$\mathrm{Cu}$} & Soil & 1 & 0.0002 & 2.33 & NS & $\mathrm{Zn}$ & Soil & 1 & 0.0001 & 3.0 & NS \\
\hline & Health & 1 & 0.00005 & 0.71 & $<0.05$ & & Health & 1 & 0.0003 & 7.7 & $<0.01$ \\
\hline & Altitude & 1 & 0.0009 & 12.65 & $<0.001$ & & Altitude & 1 & 0.000001 & 0.0 & NS \\
\hline \multirow[t]{3}{*}{$\mathrm{Fe}$} & Soil & 1 & 7.77 & 2.84 & NS & & & & & & \\
\hline & Health & 1 & 35.41 & 12.94 & $<0.001$ & & & & & & \\
\hline & Altitude & 1 & 27.38 & 10.00 & $<0.01$ & & & & & & \\
\hline
\end{tabular}

NS not significant

plants (Page and Feller 2015). The highest metal increase in autumn fronds of $A$. distentifolium from this investigation was observed for $\mathrm{Pb}$. However, the concentration of this element in fronds was proportional to the concentration of $\mathrm{Pb}$ in soil. A similar correlation for $\mathrm{Pb}$ was found for Athyrium wardii by Zou et al. (2012). Athyrium filix-femina examined in beech forests in NW Germany accumulated $\mathrm{Cd}, \mathrm{Pb}$ and $\mathrm{Cu}$ mostly in the rhizoids (Neite et al. 1991). Another member of
Athyrium, Athyrium yokoscense (a Pb hyperaccumulator), also concentrated $\mathrm{Pb}$ in rhizoids. Similarly Athyrium wardii accumulated $\mathrm{Pb}$ in rhizoids with restricted translocation to fronds (Zou et al. 2012; Zhan et al. 2018). However, whether A. distentifolium has special tolerance for $\mathrm{Pb}$ like other members of the Athyrium genus needs further investigation.

The ranges of the bioaccumulation factor BF (ratio of metal concentration in summer fronds to the

Table 4 Minimum, maximum, median and average deviation (AD) of the summer concentration $\left(\mathrm{mg} \mathrm{kg}^{-1}\right)$ of trace elements in Athyrium distentifolium from vital and non-vital plants

\begin{tabular}{|c|c|c|c|c|c|c|c|c|}
\hline & \multicolumn{4}{|l|}{ Vital } & \multicolumn{4}{|l|}{ Non-vital } \\
\hline & Minimum & Maximum & Median & $\mathrm{AD}$ & Minimum & Maximum & Median & $\mathrm{AD}$ \\
\hline $\mathrm{Cd}$ & 0.2 & 2.6 & 0.7 & 0.4 & 0.2 & 3.0 & 0.7 & 0.4 \\
\hline $\mathrm{Co}$ & $<0.04$ & 0.3 & 0.01 & 0.04 & $<0.04$ & 0.4 & 0.1 & 0.1 \\
\hline $\mathrm{Cr}$ & 0.03 & 0.6 & 0.2 & 0.1 & 0.1 & 0.6 & 0.2 & 0.1 \\
\hline $\mathrm{Cu}$ & 5.7 & 15 & 8.0 & 1.4 & 5.5 & 24 & 8.4 & 3.2 \\
\hline $\mathrm{Fe}$ & 18 & 181 & 67 & 19 & 54 & 185 & 73 & 26 \\
\hline $\mathrm{Mn}$ & 117 & 585 & 317 & 101 & 185 & 1025 & 362 & 163 \\
\hline $\mathrm{Ni}$ & 0.7 & 21 & 6.6 & 4.0 & 0.9 & 9.2 & 2.0 & 1.5 \\
\hline $\mathrm{Pb}$ & 0.4 & 3.9 & 1.3 & 0.5 & 0.2 & 4.8 & 1.4 & 1.2 \\
\hline $\mathrm{Zn}$ & 20 & 53 & 31 & 6.0 & 21 & 90 & 35 & 12 \\
\hline
\end{tabular}


Table 5 Minimum, maximum, median of the bioaccumulation factor of trace elements in summer Athyrium distentifolium from vital and non-vital plants

\begin{tabular}{|c|c|c|c|c|c|c|}
\hline \multirow{2}{*}{ 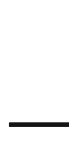 } & \multicolumn{3}{|l|}{ Vital } & \multicolumn{3}{|l|}{ Non-vital } \\
\hline & Minimum & Maximum & Median & Minimum & Maximum & Median \\
\hline $\mathrm{Cd}$ & 1.7 & 72 & 10 & 0.4 & 70 & 6.3 \\
\hline Co & 0.001 & 2.9 & 0.5 & 0.001 & 7.0 & 0.7 \\
\hline $\mathrm{Cr}$ & 0.08 & 12 & 0.6 & 0.2 & 5.3 & 1.1 \\
\hline $\mathrm{Cu}$ & 0.3 & 9.5 & 1.1 & 0.6 & 7.5 & 1.4 \\
\hline $\mathrm{Fe}$ & 0.02 & 0.4 & 0.1 & 0.02 & 0.2 & 0.1 \\
\hline Mn & 3.8 & 217 & 21 & 5.5 & 420 & 25 \\
\hline $\mathrm{Ni}$ & 0.43 & 221 & 12 & 0.5 & 21 & 4.5 \\
\hline $\mathrm{Pb}$ & 0.005 & 0.1 & 0.02 & 0.01 & 0.1 & 0.03 \\
\hline $\mathrm{Zn}$ & 0.5 & 39 & 8.1 & 0.4 & 44 & 7.5 \\
\hline
\end{tabular}

concentration of available metal in soil) are presented in Table 5. The highest median value for both vital and non-vital ferns was calculated for $\mathrm{Mn}$ and the lowest for $\mathrm{Pb}$. The Mann-Whitney $U$ test revealed that vital ferns had a significantly higher BF for $\mathrm{Ni}(p<0.05)$ and significantly lower for $\mathrm{Pb}(p<0.01)$. There was no difference between vital and non-vital plants in BF for all other trace elements. Thus, it may be supposed that the disruption of tolerance mechanisms leading to

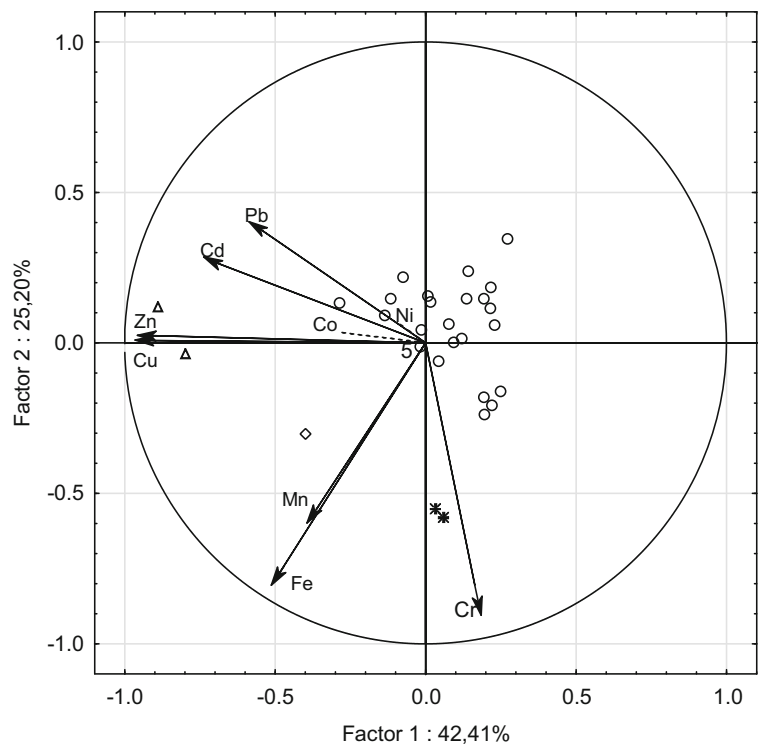

Fig. 2 Ordination plot based on the concentrations of $\mathrm{Cd}, \mathrm{Cr}, \mathrm{Cu}$, $\mathrm{Fe}, \mathrm{Mn}, \mathrm{Pb}$ and $\mathrm{Zn}$ (Co and $\mathrm{Ni}$ as supplementary variables) in Athyrium distentifolium fronds and projection of metal concentrations on the component plane. Triangles: sites 1 and 16. Diamond: sampling site 9. Stars: sites 24 and 25 elevated transport of the trace elements in non-vital fronds was not observed (Lange et al. 2016).

The Tukey test distinguished homogenous groups of sites 7 and 21 with the lowest concentrations of trace metals in fronds and 1 and 16 with the highest concentrations of these elements. Sites 1 and 16 were situated in the vicinity of waste piles near hiking trails. Additionally, the heating system of the mountain hotel in Kocioł Małego Stawu affected site 16. Thus, the local sources of pollution within the Karkonosze National Park influenced metal contents in A. distentifolium fronds. The anthropogenic impact on Polytrichum commune and Polytrichastrum formosum from Karkonosze hotels was also reported by Wojtuń et al. (2018).

Corresponding results may be observed in PCCA ordination established for metal contents in the summer fronds of $A$. distentifolium (Fig. 2). The first principal component discriminates sites 1 and 16 (negative scores). The second component discriminates sites 24 and 25 as well as site 9 (negative scores). Projection of the variables on the factor plane (Fig. 2) indicates that A. distentifolium from sites 1 and 16 was correlated with the highest concentrations of $\mathrm{Cu}$ and $\mathrm{Zn}$ in its tissues. A. distentifolium from sites 24 and 25 was correlated with the highest concentrations of $\mathrm{Cr}$ and $\mathrm{Fe}$ in its tissues. Site 9 was correlated with the highest concentrations of $\mathrm{Cr}, \mathrm{Cu}, \mathrm{Fe}$ and $\mathrm{Zn}$. Sites 24 and 25 probably received metal contamination from the Karkonosze National Park Ecological Education Centre which uses an oil heating system. Site 9 was situated in Duży Śnieżny Kocioł influenced by the Karkonosze TV and radio relay building. 
The presented investigation contributes to understanding the role of trace element pollution and behaviour in A. distentifolium growing in selected glacial cirques and their vicinity in the Karkonosze National Park and similar types of environment in the mountainous areas of Central Europe.

\section{Conclusions}

1. A. distentifolium may use accumulated tissue elements as defence against pathogens.

2. A. distentifolium at subalpine elevations contained higher concentrations of $\mathrm{Cd}, \mathrm{Cu}, \mathrm{Ni}, \mathrm{Fe}$ and $\mathrm{Pb}$ in fronds compared to lower elevations of upper forest belt.

3. A. distentifolium may sequestrate $\mathrm{Cr}, \mathrm{Cu}, \mathrm{Fe}, \mathrm{Mn}$ and $\mathrm{Pb}$ in senescing fronds probably to remove potentially harmful metals.

4. Lead was the metal with the highest increase in autumn compared to summer fronds.

5. Non-vital and vital ferns accumulated Mn proportionally to the concentration in soil.

6. Non-vital ferns were better accumulators of $\mathrm{Pb}$ than vital ones which could be caused by an increasing demand for protection against potential pathogens.

Funding information The investigation was supported by the University of Wrocław (grant no. 0420/2579/18).

\section{Compliance with ethical standards}

Conflict of interest The authors declare no conflict of interest.

Human and animal rights and informed consent This article does not contain any studies with human participants or animals performed by any of the authors.

Open Access This article is licensed under a Creative Commons Attribution 4.0 International License, which permits use, sharing, adaptation, distribution and reproduction in any medium or format, as long as you give appropriate credit to the original author(s) and the source, provide a link to the Creative Commons licence, and indicate if changes were made. The images or other third party material in this article are included in the article's Creative Commons licence, unless indicated otherwise in a credit line to the material. If material is not included in the article's Creative Commons licence and your intended use is not permitted by statutory regulation or exceeds the permitted use, you will need to obtain permission directly from the copyright holder. To view a copy of this licence, visit http://creativecommons.org/licenses/by/4.0/.

\section{References}

Aboal, J. R., Fernández, J. A., \& Carballeira, A. (2004). Oak leaves and pine needles as biomonitors of airborne trace elements pollution. Environmental and Experimental Botany, 51, 215-225.

Argaç, D. (2004). Testing for homogeneity in a general one-way classification with fixed effects: Power simulations and comparative study. Computational Statistics \& Data Analysis, 44, 603-612.

Becker, K. W., \& Skaar, E. P. (2014). Metal limitation and toxicity at the interface between host and pathogen. FEMS Microbiology Reviews, 38, 1235-1249.

Brown, M. B., \& Forsythe, A. B. (1974). Robust tests for the equality of variances. Journal of the American Statistical Association, 69, 364-367.

Chang, J. S., Yoon, I. H., \& Kim, K. W. (2009). Heavy metal and arsenic accumulating fern species as potential ecological indicators in As-contaminated abandoned mines. Ecological Indicators, 9, 1275-1279.

Cheruiyot, D. J., Boyd, R. S., \& Moar, W. J. (2013). Exploring lower limits of plant elemental defence by cobalt, copper, nickel, and zinc. Journal of Chemical Ecology, 39, 666-674.

Cornara, L., Roccotiello, E., Minganti, V., Drava, G., De Pellegrini, R., \& Mariotti, M. G. (2007). Level of trace elements in Pteridophytes growing on serpentine and metalliferous soils. Journal of Plant Nutrition and Soil Science, 170, 781-787.

Cottenie, A., Verloo, M., Kiekens, L., Velghe, G., \& Camerlynck, R. (1982). Chemical analysis of plants and soils. Instituut tot Aanmoediging van het Wetenschappelijk Onderzoek in Nijverheid en Landbouw (I.W.O.N.L.), Brussels, Belgium.

Dell, Inc. (2015). Dell Statistica (data analysis software system), version 13. software.dell.com.

Dunajski, A., Szymura, T. H., \& Szymura, M. (2016). Recent high mountain vegetation structure in the Karkonosze Mts Results from the system of permanent plots. Fragmenta Floristica et Geobotanica Polonica, 23, 57-72.

Eskandari, S., Khoshgoftarmanesh, A. H., \& Sharifnabi, B. (2018). The effect of foliar-applied manganese in mineral and complex forms with amino acids on certain defense mechanisms of cucumber (Cucumis sativus L.) against powdery mildew. Journal of Plant Growth Regulation, 37, 481490.

Fones, H., Davis, C. A. R., Rico, A., Fang, F., Smith, J. A. C., \& Preston, G. M. (2010). Metal hyperaccumulation armors plants against disease. PLoS Pathogens, 6(9), e1001093. https://doi.org/10.1371/journal.ppat.1001093.

Fones, H. N., Preston, G. M., \& Smith, J. A. C. (2019). Variation in defence strategies in the metal hyperaccumulator plant Noccaea caerulescens is indicative of synergies and tradeoffs between forms of defence. Royal Society Open Science, $6,172418$.

Fudali, E. (2010). Mosses of Kocioł Łomniczki glacial cirque (Karkonosze Mts) in relation to ecological and 
phytocoenotical diversity of habitats. Rocz. AR Pozn.389. Botanika-Steciana, 14, 11-17.

Gerdol, R., \& Bragazza, L. (2006). Effects of altitude on element accumulation in alpine moss. Chemosphere, 64, 810-816.

Harmens, H., Büse, A., Buker, P., Norris, D., Mills, G., Williams, B., Reynolds, B., Ashenden, T. W., Rühling, A., \& Steinnes, E. (2004). Heavy metal concentrations in European mosses: 2000/2001 survey. Journal of Atmospheric Chemistry, 49, 425-436.

Holoubek, I., Korinek, P., Seda, Z., Schneiderova, E., Holoubkova, I., Pacl, A., Triska, J., Cudlin, P., \& Caslavsky, J. (2000). The use of mosses and pine needles to detect persistent organic pollutants at local and regional scales. Environmental Pollution, 109, 283-292.

Jeník, J. (1961). Alpinská vegetace Krkonoš, Králického Sněžníku a Hrubého Jeseniku: teorie anemo-orografických systémů. Praha: Nakladatelství ČSAV.

Kabała, C., \& Szerszeń, L. (2002). Profile distributions of lead, zinc, and copper in dystric cambisols developed from granite and gneiss of the Sudetes mountains, Poland. Water Air and Soil Pollution, 138, 307-317.

Kabata-Pendias, A. (2001a). Trace elements in soils and plants. Boca Raton: CRC Press.

Kabata-Pendias, A. (2001b). Trace metals in soils-a current issue in Poland. Acta Universitatis Wratislaviensis 2317. Prace Botaniczne, 79, 13-20.

Kachenko, A. G., Singh, B., \& Bhatia, N. P. (2007). Heavy metal tolerance in common fern species. Australian Journal of Botany, 55, 63-73.

Kamachi, H., Kitamura, N., Sakatoku, A., Tanaka, D., \& Nakamura, S. (2015). Barium accumulation in the metalliferous fern Athyrium yokoscense. Theoretical and Experimental Plant Physiology, 27, 99-107.

Killingbeck, K. T., Hammen-Winn, S. L., Vecchio, P. G., \& Goguen, M. E. (2002). Nutrient Resorption Efficiency and Proficiency in Fronds and Trophopods of a WinterDeciduous Fern,Dennstaedtia punctilobula. International Journal of Plant Sciences, 163, 99-105.

Kłos, A. (2009). Zastosowanie współczynnika wzbogacenia (EF) do interpretacji wyników badań biomonitoringowych [application of enrichment factor (EF) for intepretation of the results of biomonitoring studies]. Chemia, Dydaktyka, Ekologia, Metrologia, 14, 49-55.

Kovár, P. (2015). Conceptions of landscape-ecological relevance emerged in the Czech botany during the second half of twentieth century. Journal of Landscape Ecology, 8, 40-50.

Kozanecka, T., Chojnicki, J., \& Kwasowski, W. (2002). Content of heavy metals in plant from pollution-free regions. Polish Journal of Environmental Studies, 11, 395-399.

Krawczyk, J., Letachowicz, B., Klink, A., \& Krawczyk, A. (2006). Zróżnicowanie kumulacji metali ciężkich w Athyrium filix-femina (L.)Roth. i Athyrium distentifolim Tausch ex Opiz z Sowiej Doliny i Doliny Łomniczki (Karkonosze Wschodnie) oraz ich wykorzystanie do oceny stanu środowiska [The diversity of heavy metal accumulation in Athyrium filix-femina (L.)Roth. and Athyrium distentifolim Tausch ex Opiz from the Sowia Dolina and Dolina Łomniczki (Eastern Karkonosze Mts.) and the use of these ferns for evaluation of environmental conditions]. Zeszyty Problemowe Postepu Nauk Rolniczych 515: 211-217.
Lange, B., van der Ent, A., Baker, A. J., Echevarria, G., Mahy, G., Malaisse, F., Meerts, P., Pourret, O., Verbruggen, N., \& Faucon, M. P. (2016). Copper and cobalt accumulation in plants: A critical assessment of the current state of knowledge. New Phytologist, 213, 537-551.

Legendre, P., \& Legendre, L. (1998). Numerical ecology. Amsterdam: Elsevier.

Markert, B., Herpin, U., Berlekamp, J., Oehlmann, J., Grodzinsk, K., Mankovska, B., Suchara, I., Siewers, U., Weckert, V., \& Lieth, H. A. (1996). Comparison of heavy metal deposition in selected eastern European countries using the moss monitoring method, with special emphasis on the "black triangle". Science of the Total Environment, 193, 85-100.

McHaffie, H. S. (2005). Athyrium distentifolium Tausch ex Opiz (a. alpestre(Hoppe) Rylands ex T. Moore-non-Clairv.) including A. distentifolium var. flexile (Newman) Jermy. Journal of Ecology, 93, 839-851.

Mochnacka, K., \& Banaś, M. (2000). Occurrence and genetic relationships of uranium and thorium mineralization in the Karkonosze Izera block (the Sudety Mts, SW Poland). Annales Societatis Geologorum Poloniae, 70, 137-150.

Morkunas, I., Woźniak, A., Mai, V. C., Rucińska-Sobkowia, R., \& Jeandet, P. (2018). The role of heavy metals in plant response to biotic stress. Molecules, 23, 2320. https://doi.org/10.3390 /molecules23092320.

Neite, H., Neikes, N., \& Wittig, R. (1991). Verteilung von Schwer meta lien im Wurzel bereich und den Organen von Waldbodenpflanzen aus Buchenwaldern [distribution of heavy metals in the root area and $\mathrm{m}$ organs of herbaceous plants in beech forests]. Flora, 185, 325-333 [Engl.Summ.].

Oliva, S. R., \& Rautio, P. (2004). Could ornamental plants serve as passive biomonitors in urban areas? Journal of Atmospheric Chemistry, 49, 137-138.

Page, V., \& Feller, U. (2015). Heavy metals in crop plants: Transport and redistribution processes on the whole plant level. Agronomy, 5, 447-463.

Pusz, W. (2016). Plants' healthiness assessment as part of the environmental monitoring of protected mountainous area in the example of Karkonosze (Giant) Mts. (SW Poland). Environmental Monitoring and Assessment, 188, 544. https://doi.org/10.1007/s10661-016-5551-5.

Quinn, G. P., \& Keough, M. J. (2002). Experimental design and data analysis for biologists. Cambridge University Press.

Rybczyński, J. J., \& Mikuła, A. (2011). Tree ferns biotechnology: From spores to sporophytes. In H. Fernández, A. Kumar, \& M. A. Revilla (Eds.), Working with ferns, issues and applications. New York: Springer.

Samecka-Cymerman, A., Stankiewicz, A., Kolon, K., Kempers, A. J., \& Musiał, M. (2012). Athyrium distentifolium used for bioindication at different altitudes in the Tatra National Park (South Poland). Ecotoxicology and Environmental Safety, 79, 184-188.

Schmidt, S. R., Kleinebecker, T., Vogel, A., \& Holzel, N. (2010). Interspecific and geographical differences of plant tissue nutrient concentrations along an environmental gradient in Southern Patagonia, Chile. Aquatic Botany, 92, 149-156.

Shetekauri, S., Shetekauri, T., Kvlividze, A., Chaligava, O., Kalabegishvili, T., Kirkesali, E. I., Frontasyeva, M. V., \& Chepurchenko, O. E. (2015). Preliminary results of atmospheric deposition of major and trace elements in the greater and lesser Caucasus Mountains studied by the moss 
technique and neutron activation analysis. Annali di Botanica, 5, 89-95.

Snedecor, G. W., \& Cochran, W. G. (1989). Statistical methods, 8thEd. Ames: Iowa State Univ. Press Iowa.

Štursa, J. (1998). Research and management of the Giant Mountains' arctic-alpine tundra (Czech Republic). Ambio, 27, 358-360.

Szopka, K., Karczewska, A., \& Kabała, C. (2011). Mercury accumulation in the surface layers of mountain soils: A case study from the Karkonosze Mountains, Poland. Chemosphere, 83, 1507-1512.

Urban, G., Migała, K., \& Pawliczek, P. (2017). Sunshine duration and its variability in the main ridge of the Karkonosze Mountains in relation to with atmospheric circulation. Theoretical and Applied Climatology. https://doi. org/10.1007/s00704-017-2035.

Vacek, S., Bastl, M., \& Lepš, J. (1999). Vegetation changes in forests of the Krkonoše Mts. over a period of air pollution stress (1980-1995). Plant Ecology, 143, 1-11.

Waroszewski, J., Kaliński, K., Malkiewicz, M., Gąsiorek, R., Kozłowski, G., \& Kabała, C. (2013). Pleistocene-Holocene cover-beds on granite regolith as parent material for Podzols - An example from the Sudeten Mountains. Catena, 103, 111.

Weiss, G., \& Carver, P. L. (2018). Role of divalent metals in infectious disease susceptibility and outcome. Clinical Microbiology and Infection, 24, 16-12.

Wojtuń, B., Samecka-Cymerman, A., Kolon, K., \& Kempers, A. J. (2013a). Decreasing concentrations of metals in Sphagnum mosses in ombrotrophic mires of the Sudety mountains (SW Poland) since late 1980s. Chemosphere, 91, 1456-1461.

Wojtuń, B., Samecka-Cymerman, A., Kolon, K., Klink, A., \& Kempers, A. J. (2013b). Andromeda polifolia and Oxycoccus microcarpus as pollution indicators for ombrotrophic bogs in the Western Sudety Mountains (SW Poland). Journal of Environmental Science and Health, Part A, 48, 686-693.
Wojtuń, B., Samecka-Cymerman, A., Żołnierz, L., Rajsz, A., \& Kempers, A. J. (2017). Vascular plants as ecological indicators of metals in alpine vegetation (Karkonosze, SW Poland). Environ Science and Pollution Research, 24, 20093-20103.

Wojtun, B., Samecka-Cymerman, A., Kosiba, P., Kempers, A. J., \& Rajsz, A. (2018). Trace elements in Polytrichum commune and Polytrichastrum formosum from the Karkonosze Mountains (SW Poland). Ecotoxicology and Environmental Safety, 153, 1-7.

Zar, H. (1999). Biostatistical analysis. Upper Saddle River: Prentice Hall.

Zechmeister, H. G. (1995). Correlation between altitude and heavy metal deposition in the Alps. Environmental Pollution, 89, 73-80.

Zhan, J., Li, T., Yu, H., \& Zhan, X. (2018). Cd and Pb accumulation characteristics of phytostabilizer Athyrium wardii (Hook.) grown in soils contaminated with cd and $\mathrm{Pb}$. Environ Science and Pollution Research, 25, 29026-29037.

Zhang, S. J., Li, T. X., Huang, H. G., Zhang, X. Z., Yu, H. Y., Zheng, Z. C., Wang, Y. D., Zou, T. J., Hao, X. Q., \& Pu, Y. (2014). Phytoremediation of cadmium using plant species of Athyrium wardii (Hook.). International Journal of Environmental Science and Technology, 11, 757-764.

Żołnierz, L., Wojtuń, B., \& Przewoźnik, L. (2012). Ekosystemy nieleśne Karkonoskiego Parku Narodowego [Non forest ecosystems of Karkonosze National Park]. Karkonoski Park Narodowy Jelenia Góra, 24-25 [Engl. Sum].

Zou, T., Li, T., Zhang, X., Yu, H., \& Huang, H. (2012). Lead accumulation and phytostabilization potential of dominant plant species growing in a lead-zinc mine tailing. Environmental Earth Sciences, 65, 621-630.

Zuur, A., Ieno, E. N., \& Smith, G. M. (2007). Analysing ecological data. Springer Science, Business Media, LLC.

Publisher's note Springer Nature remains neutral with regard to jurisdictional claims in published maps and institutional affiliations. 